\title{
PENYIANGAN BUKU DITINJAU DARI PERSPEKTIF PENGELOLAAN BARANG MILIK NEGARA
}

\author{
Ambang Aries Yudanto ${ }^{1}$ dan Tiana Dewi Anggraeni ${ }^{2}$ \\ Politeknik Keuangan Negara STAN \\ E-mail : ariesyudanto@pknstan.ac.id ${ }^{1}$, tiana.dewi.anggraeni@gmail.com ${ }^{2}$ \\ INFORMASI ARTIKEL

\section{ABSTRAK}

\section{File Diterima: \\ [01 Juni 2020]}

Revisi:

[10 Juni 2020]

\section{Diterima:}

[20 Juni 2020]

\section{Kata Kunci:}

Penyiangan, Weeding, Barang Milik Negara, Buku, Pemusnahan, Penghapusan.

\section{Klasifikasi Jel:}

[Untuk klasifikasi keywords menggunakan standard JEL codes yang dapat diakses pada http://www.aeaweb.org/jel/guide/jel.php].
This study aims to determine the process of weeding the book collection which utilize the perspective of State Property (BMN) Management, especially from the process of the destruction and removal of BMN. This study took a locus at Library Unit, Politeknik Keuangan Negara STAN. Most of the books located in the PKN STAN Library are part of BMN. The results of the discussion of this study found that the follow-up of weeding books in the form of destroying BMN was not carried out, and it was more likely to be removed from the BMN's database. This approach might generate more economical result since it was able to optimize the residual economic value. The problems found with regards to the research questions were related to limited human resources, limited storage space, physical data accuracy, and in the process of determining the sales limit value..

Penelitian ini bertujuan untuk mengetahui proses penyiangan koleksi buku (weeding) dan ditinjau dari perspektif Pengelolaan Barang Milik Negara (BMN), terutama dari sisi proses Pemusnahan dan Penghapusan BMN. Penelitian ini mengambil lokus pada Unit Perpustakaan Politeknik Keuangan Negara STAN. Koleksi Buku yang terdapat pada Perpustakaan PKN STAN sebagian besar merupakan bagian dari BMN. Hasil diskusi dari penelitian ini mendapati bahwa tindak lanjut dari penyiangan buku berupa pemusnahan BMN tidak dilakukan, dan lebih cenderung untuk dilakukan penghapusan karena secara umum lebih mampu mengoptimalkan nilai ekonomis residual-nya. Permasalahan yang ditemukan berkaitan dengan keterbatasan Sumber Daya Manusia, Keterbatasan Ruang Tandon, Akurasi data fisik, dan dalam proses penentuan nilai limit penjualan. 


\section{PENDAHULUAN}

\subsection{Latar Belakang}

Perpustakaan merupakan sumber informasi untuk mengumpulkan, mengolah, dan menampilkan bahan Pustaka (penelitian, karya cetak dan/atau karya rekam) sehingga dapat digunakan dan memenuhi kebutuhan pengguna, baik yang bertujuan untuk pendidikan maupun penelitian atau bahkan sekedar rekreasi (UU Nomor 43 Tahun 2007 tentang Perpustakaan; Rahayu \& Rahmah, 2013). Guna memenuhi kebutuhan pengguna, perpustakaan dituntut untuk menyediakan koleksi yang lengkap sesuai dengan perkembangan teknologi informasi dan ilmu pengetahuan. Hal ini dikarenakan lembaga perpustakaan tidak terlepas dari kebutuhan peradaban manusia, baik sebagai tempat rujukan, sarana pembelajaran maupun perkembangan keilmuan lainnya. Seperti situasi saat ini, perpustakaan telah menjadi salah satu pusat informasi, pusat ilmu pengetahuan, penelitian, dan pelestarian khasanah budaya bangsa.

Untuk itulah, berbagai bahan koleksi yang terdapat di dalam perpustakaan perlu sesuai dengan tujuan dan lingkungan dimana perpustakaan itu berada, seperti halnya di lingkungan Perguruan Tinggi (Ridwan \& Rohana, 2020). Perpustakaan perguruan tinggi merupakan bagian integral dalam implementasi pelaksanaan Tridharma, yaitu mendukung pelaksanaan Pendidikan, penelitian/riset, dan pengabdian kepada masyarakat dan berfungsi sebagai pusat sumber belajar guna mendukung tercapainya tujuan Pendidikan pada Perguruan Tinggi (PNRI, 2017; Sutarno, 2006).

Sebagai salah satu upaya mendukung pencapaian tujuan di atas, Perpustakaan Perguruan Tinggi perlu menyediakan materi koleksi yang mutakhir. Penyesuaian koleksi dari waktu ke waktu menyebabkan koleksi lama menjadi tidak digunakan secara optimal. Oleh karena itu, maka diperlukan kegiatan penyiangan bahan Pustaka atau weeding (Rahayu \& Rahmah, 2013). Penyiangan merupakan proses menentukan koleksi apa saja yang akan ditarik secara permanen dan merumuskan kriteria koleksi yang akan disiangkan (J. G. Sujana, 2011).

Penyiangan ini menjadi semakin menarik ketika dikaitkan dengan Pengelolaan Barang Milik Negara (BMN), dimana koleksi yang terdapat di dalam Perpustakaan Perguruan Tinggi tersebut merupakan bagian dari BMN. Dalam pelaksanaan Pengelolaan BMN, BMN merupakan bagian dari aset pemerintah pusat yang berwujud yang dibedakan menjadi tanah; peralatan dan mesin; gedung dan bangunan; jalan, irigasi, dan jaringan; aset tetap lainnya; serta konstruksi dalam pengerjaan. Bersumber pada Pernyataan Standar Akuntansi Pemerintah (PSAP) Nomor 07 yang terdapat dalam Lampiran Peraturan Pemerintah Nomor 71 Tahun 2010, buku termasuk bagian dari aset tetap lainnya. Meskipun nilai kapitalisasi buku di bawah nilai kapitalisasi minimal, buku tetap digolongkan ke dalam aset tetap. Hal tersebut dikarenakan buku memiliki nilai manfaat lebih dari satu tahun, digunakan untuk kegiatan operasional, dan dijadikan sebagai inventaris. Jika dilihat dari sudut pandang pemusnahan dan penghapusan dalam siklus pengelolaan BMN, proses tersebut merupakan hal yang kerap terjadi di lingkungan pemerintahan. Namun, pemusnahan buku menjadi hal yang langka dikarenakan buku selaku barang, masih memiliki nilai jual.

Sebagai salah satu Perguruan Tinggi sekaligus juga satuan kerja di bawah Kementerian Keuangan (Kementerian Keuangan, 2015), Politeknik Keuangan Negara STAN (PKN STAN) tentunya memiliki BMN berupa buku yang jumlahnya tidak sedikit karena buku mendukung kegiatan tridharma-nya. Di lain sisi, koleksi-koleksi tersebut secara periodik perlu untuk dilakukan penyiangan untuk menjaga kualitas koleksi serta menjaga ketersediaan ruang simpan untuk koleksi yang lebih baru. Adapun koleksi-koleksi tersebut merupakan koleksi yang perlu untuk dikelola oleh Unit Perpustakaan seperti yang ditulis dalam PMK Nomor 157 Tahun 2015 tentang Organisasi dan Tata Kelola Politeknik Keuangan Negara STAN.

Berdasarkan hal-hal tersebut di atas, tujuan penelitian ini adalah untuk mendeskripsikan kegiatan penyiangan/weeding koleksi berupa buku (dalam hal ini yang merupakan BMN) yang dilakukan oleh Perpustakaan PKN STAN dengan perspektif Pengelolaan BMN terutama dari proses Pemusnahan dan Penghapusan BMN.

\subsection{Tujuan}

Dalam penulisan penelitian ini ada beberapa tujuan yang ingin penulis capai, yaitu:

1. Mengetahui praktik penyiangan buku ditinjau dari perspektif pemusnahan BMN.

2. Mengetahui praktik penyiangan buku ditinjau dari perspektif penghapusan BMN.

3. Mengetahui permasalahan dan kendala yang muncul selama proses pemusnahan dan penghapusan BMN berupa buku.

\section{LANDASAN TEORI}

\subsection{Penyiangan/Weeding}

Penyiangan bahan pustaka merupakan kegiatan mengembangkan koleksi buku dengan cara mengeluarkan atau mengeluarkan koleksi dari rak untuk kemudian disimpan di dalam ruangan. Menurut penelitian Masridah, 2009, penyiangan adalah pekerjaan menyegarkan koleksi yang rusak, koleksi tersebut banyak eksemplar, versi baru, dilarang oleh pemerintah, tidak dalam bahasa terbaru, pengguna kurang paham dengan bahasanya, dan sebagainya. Kegiatan ini dilakukan agar koleksi di perpustakaan dapat digunakan secara optimal, dan efisen tempat, sehingga koleksi selalu fresh dan diminati oleh pengguna.

Lebih lanjut, penyiangan adalah suatu kegiatan, seperti mengeluarkan materi dari koleksi kegiatan untuk dibuang atau dipindahkan. Pilih dari ruang referensi perpustakaan secara bergiliran, pisahkan atau hilangkan koleksi, agar koleksi tersebut tetap 
relevan dan dapatkan informasi berdasarkan waktu (Johnson, 2009). Selain itu, menurut Manar, 2010, penyiangan koleksi merupakan salah satu alternatif untuk menyaring bahan pustaka yang dianggap sudah tidak optimal bagi perpustakaan. Menyiangi koleksi adalah aktivitas yang menghapus koleksi dari katalog karena rusak atau terduplikasi. Sebelum pengguna terlibat dalam kegiatan penyiangan, pustakawan harus terlebih dahulu memahami standar kriteria koleksi yang layak untuk disiangi. Standar ini ditentukan oleh pustakawan pengembangan koleksi dengan berkonsultasi dengan pustakawan dan staf pengajar.

Selanjutnya, kriteria penyiangan didasarkan pada kombinasi karakteristik sebagai berikut: [1] Tidak lagi digunakan karena sudah kedaluwarsa; [2] Menggunakan bahasa yang tidak familiar bagi pengguna; [3] Area subjek tidak cocok untuk koleksi; [4] Jarang digunakan/tidak digunakan dalam waktu lama; [5] Jumlah kopi yang tidak memenuhi persyaratan (Almah, 2012). Selain itu, menurut Y. Y. Sujana, 2009, standar umum untuk penyiangan adalah sebagai berikut: [1] Buku terkait kuliah tidak lagi memenuhi kebutuhan pemustaka; [2] Isi perpustakaan sudah usang; [3] terdapat kolesi versi terbaru; [4] Bahan pustaka terlalu rusak untuk diperbaiki.

\subsection{Pengelolaan Barang Milik Negara}

Menurut Peraturan Pemerintah Nomor 27 Tahun 2014 tentang Pengelolaan Barang Milik Negara, BMN adalah semua barang yang dibeli atau diperoleh atas beban Anggaran Pendapatan dan Belanja Negara (APBN) atau berasal dari perolehan lainnya yang sah. Perolehan lainnya yang sah meliputi:

a. Barang yang diperoleh dari hibah/sumbangan atau yang sejenis

b. Barang yang diperoleh sebagai pelaksanaan dari perjanjian/kontrak

c. Barang yang diperoleh sesuai dengan ketentuan peraturan perundang-undangan

d. Barang yang diperoleh berdasarkan putusan pengadilan yang telah berkekuatan hukum tetap

Pelaksanaan pengelolaan barang milik negara, pemerintah berpedoman pada akuntansi pemerintahan. Berdasarkan Sistem Akuntansi Pemerintah Pusat, barang milik negara merupakan bagian dari aset pemerintah pusat yang berwujud yang dibedakan menjadi tanah; peralatan dan mesin; gedung dan bangunan; jalan, irigasi, dan jaringan; aset tetap lainnya; serta konstruksi dalam pengerjaan. Bersumber pada klasifikasi di atas, buku termasuk bagian dari aset tetap lainnya. Meskipun nilai kapitalisasi buku di bawah nilai kapitalisasi minimal, buku tetap digolongkan ke dalam aset tetap dikarenakan hal-hal berikut, antara lain:

a. Nilai manfaat lebih dari satu tahun;

b. Digunakan untuk kegiatan operasional; dan

c. Dijadikan sebagai inventaris.

Berdasarkan Undang-Undang Nomor 3 Tahun 2017 tentang Sistem Perbukuan, buku adalah penelitian dan/atau karya gambar yang diterbitkan berupa cetakan berjilid atau berupa publikasi elektronik yang diterbitkan secara tidak berkala. Buku dibedakan menjadi dua bentuk, antara lain:

a. Buku cetak

Buku cetak merupakan penelitian yang berupa teks, gambar, atau gabungan dari keduanya yang dipublikasikan dalam bentuk cetak.

b. Buku elektronik

Buku elektronik merupakan penelitian yang berupa teks, gambar, audio, video, atau gabungan dari keseluruhannya yang di publikasikan dalam bentuk elektronik.

Pengelolaan Barang Milik Negara/Daerah dilaksanakan berdasarkan asas fungsional, kepastian hukum, transparansi, efisiensi, akuntabilitas, dan kepastian nilai. Pengelolaan Barang Milik Negara/Daerah meliputi:

a. Perencanaan Kebutuhan dan penganggaran;

b. pengadaan;

c. Penggunaan;

d. Pemanfaatan;

e. pengamanan dan pemeliharaan;

f. Penilaian;

g. Pemindahtanganan;

h. Pemusnahan;

i. Penghapusan;

j. Penatausahaan; dan

k. pembinaan, pengawasan dan pengendalian.

\subsection{Pemusnahan dan Penghapusan BMN}

Pemusnahan Barang Milik Negara dilakukan dalam hal Barang Milik Negara sudah tidak dapat digunakan, tidak dapat dimanfaatkan, tidak dapat dipindahtangankan atau alasan lainnya sesuai ketentuan peraturan perundang-undangan. Pemusnahan Barang Milik Negara harus mempertimbangkan tidak adanya unsur kerugian bagi Negara dan kesejahteraan masyarakat.

Pemusnahan BMN dilaksanakan oleh Pengguna Barang setelah mendapat persetujuan dari Pengelola Barang dan dilaporkan Pelaksanaannya dengan dituangkan dalam Berita Acara. Sesuai dengan PMK nomor 4 /PMK.06/2015 tentang Pendelegasian Kewenangan dan Tanggungjawab Tertentu dari Pengelola Barang kepada Pengguna Barang. Persetujuan pemusnahan yang diberikan oleh pengguna barang terdiri dari pemusnahan atas:

a. Persediaan;

b. Aset Tetap Lainnya berupa hewan: ikan dan tanaman;

c. Selain tanah dan/atau bangunan, yang tidak mempunyai dokumen kepemilikan, dengan nilai perolehan sampai dengan Rp100.000.000,00 (seratus juta rupiah) per unit/satuan; dan

d. Bongkaran BMN karena perbaikan (renovasi, rehabilitasi, atau restorasi) diberikan oleh Pengguna Barang.

Bentuk-bentuk pemusnahan antara lain dengan cara dibakar, dihancurkan, ditimbun, ditenggelamkan, atau cara lain sesuai ketentuan.

Sedangkan Penghapusan Barang Milik Negara adalah tindakan menghapus BMN dari daftar barang dengan menerbitkan keputusan dari pejabat yang 
berwenang untuk membebaskan Pengelola Barang, Pengguna Barang, dan/ atau Kuasa Pengguna Barang dari tanggung jawab administrasi dan fisik atas barang yang berada dalam penguasaannya.

BMN yang ditatausahakan oleh Kuasa Pengguna Barang secara fisik dapat tidak berada lagi dalam penguasaan Kuasa Pengguna Barang karena beberapa sebab seperti:

a. BMN yang bersangkutan diserahkan ke pengelola;

b. BMN dialihstatuskan ke Pengguna Barang/Kuasa Pengguna Barang yang lain;

c. BMN telah dipindahtangankan;

d. Pemusnahan; dan

e. Sebab-sebab lain.

Sebab-sebab lain sebagaimana dimaksud di atas merupakan sebab-sebab yang secara normal dapat diperkirakan wajar menjadi penyebab Penghapusan, antara lain:

a. Hilang, kecurian, terbakar, susut, menguap, dan mencair;

b. Mati untuk hewan, ikan, dan tanaman;

c. Harus dihapuskan untuk bangunan yang berdiri di atas tanah Pihak Lain atau Pemerintah Daerah karena tidak dapat dilakukan Pemindahtanganan;

d. Harus dihapuskan untuk Aset Tetap Renovasi (ATR) atas aset milik Pihak Lain karena tidak dapat dilakukan Pemindahtanganan;

e. Harus dihapuskan untuk bangunan dalam kondisi rusak berat dan/ atau membahayakan lingkungan sekitar;

f. Harus dihapuskan untuk bangunan yang berdiri di atas tanah yang menjadi objek pemanfaatan dalam bentuk Kerjasama Pemanfaatan, Bangun Guna Serah/Bangun Serah Guna atau Kerjasama Penyediaan Infrastruktur, setelah bangunan tersebut diperhitungkan sebagai investasi pemerintah;

g. Harus dihapuskan karena anggaran untuk bangunan pengganti sudah disediakan dalam dokumen penganggaran;

h. Sebagai akibat dari keadaan kahar (force majeure). Sebab-sebab lain yang secara normal dapat diperkirakan wajar menjadi penyebab penghapusan untuk BMN berupa aset tak berwujud antara lain karena tidak sesuai dengan perkembangan teknologi, tidak sesuai dengan kebutuhan organisasi, rusak berat, atau masa manfaat/kegunaan telah berakhir.

Penghapusan BMN sebagaimana dimaksud di atas dilakukan dengan menerbitkan keputusan Penghapusan BMN dari Pengguna Barang setelah mendapat persetujuan dari Pengelola Barang. Dikecualikan dari ketentuan mendapat persetujuan Penghapusan dari Pengelola Barang sebagaimana dimaksud di atas untuk BMN yang dihapuskan karena:

a. Pengalihan Status Penggunaan;

b. Pemindahtanganan; dan

c. Pemusnahan.

Pengalihan

Status

Penggunaan,

Pemindahtanganan serta Pemusnahan telah dilakukan dengan mendapat persetujuan Pengelola. Untuk BMN pada pengguna berupa Persediaan, aset Tetap Lainnya berupa hewan, ikan dan tanaman, selain tanah dan/atau bangunan, yang tidak mempunyai dokumen kepemilikan, dengan nilai perolehan sampai dengan Rp100.000.000,00 (seratus juta rupiah) per unit/satuan dan harus dihapuskan karena sebab-sebab lain, penghapusannya mendapat persetujuan Pengguna Barang (PMK no 4/PMK.06/2015 pasal 7). Sebab-sebab lain yang merupakan sebab-sebab secara normal dapat diperkirakan wajar menjadi penyebab penghapusan, adalah seperti rusak berat yang tidak bernilai ekonomis, hilang, susut, menguap, mencair, kadaluwarsa, mati/cacat berat/tidak produktif untuk tanaman/hewan, dan sebagai akibat dari keadaan kahar (force majeure). Terakhir, Pelaksanaan Penghapusan BMN dilaporkan kepada Pengelola Barang.

\section{METODOLOGI PENELITIAN}

\subsection{Metode Penelitian}

Jenis penelitian ini adalah metode penelitian deskriptif kualitatif, yang hanya mengembangkan konsep dan mengumpulkan fakta, tetapi tidak menguji hipotesis. Oleh karena itu, penelitian ini dibatasi pada pekerjaan yang mengungkapkan tema penelitian saat ini atau status objek penelitian berdasarkan faktafakta yang terlihat atau dengan dukungan metode studi kepustakaan, studi documenter, dengan wawancara dan observasi yang selanjutnya akan dijelaskan lebih detail pada sub-bagian setelah ini.

Penelitian ini mengambil lokus di Perpustakaan Politeknik Keuangan Negara STAN dan dilaksanakan pada periode bulan Februari sampai dengan Juli 2020. Ruang lingkup penelitian ini dari perspektif Pengelolaan BMN dan lebih menyoroti dari tahapan Pemusnahan dan Penghapusan BMN yang secara langsung ada kaitan dengan Penyiangan Koleksi Perpustakaan berupa buku. Lebih lanjut, koleksi buku disini diartikan merupakan koleksi buku yang masuk dalam kategori Barang Milik Negara.

\subsection{Proses Pengumpulan Data}

\subsubsection{Studi Kepustakaan}

Studi kepustakaan dalam penelitian ini ditujukan untuk menampilkan informasi yang berkaitan dengan latar belakang dan kajian teoritis. Studi kepustakaan yang dipakai berupa peraturan perundang-undangan yang berhubungan dengan pengelolaan barang milik negara dan buku serta dokumen-dokumen publik berupa jurnal publikasi baik nasional maupun internasional. Penulis juga mengambil beberapa referensi lain mengenai kedua hal tersebut baik offline maupun online untuk menambah dasar penyusunan penelitian sehingga tidak hanya bersumber pada peraturan yang ada.

\subsubsection{Studi Dokumenter}

Studi dokumentasi merupakan pengumpulan data melalui dokumen-dokumen yang diperlukan melalui peninggalan tertulis, seperti arsip, buku, teori, pendapat, dalil, hukum, dan lain-lain yang berhubungan dengan penelitian yang dilakukan. Penulis melakukan studi dokumenter di Bagian Keuangan dan Umum PKN STAN pada tanggal 21 April 
2020 dan 7 Juli 2020 serta di Unit Perpustakaan PKN STAN pada tanggal 12 Mei 2020.

\subsubsection{Wawancara}

Menurut Muri Yusuf (2014:372), wawancara merupakan percakapan tatap muka (face to face) antara pewawancara dengan informan, dimana pewawancara bertanya langsung tentang suatu objek yang diteliti dan telah dirancang sebelumnya. Dalam penelitian ini yang dimaksud dengan informan adalah sosok yang dianggap mengetahui dengan baik terhadap permasalahan yang diteliti dan bersedia menyampaikan informasi kepada peneliti. Pemilihan informan didasarkan pada penentuan informan yang dilakukan dengan subjek berdasarkan kriteria tertentu (purposive). Dalam penulisan penelitian ini, wawancara dilakukan kepada tiga narasumber, antara lain A1, selaku Kepala Unit Perpustakaan Politeknik Keuangan Negara STAN, pada tanggal 23 April 2020; A2, selaku pegawai pada Bagian Keuangan dan Umum, pada tanggal 21 April 2020 dan 10 Juni 2020; serta A3, Tenaga Layanan Pemustaka Unit Perpustakaan Politeknik Keuangan Negara STAN, pada tanggal 23 Juni 2020. Wawancara secara langsung, diaplikasikan untuk menggali data tentang pelaksanaan penyiangan buku dan dikaitkan dengan pelaksanaan pemusnahan dan penghapusan buku di Politeknik Keuangan Negara STAN.

\subsubsection{Observasi}

Observasi yaitu metode penelitian yang digunakan untuk mengetahui dan menyelidiki tingkah laku nonverbal sehingga mendapatkan data primer dan pemahaman yang mendalam terkait permasalahan yang dibahas. Observasi yang dilakukan penulis berupa pengamatan dan pencatatan terhadap situasi sebenarnya di lapangan yang mana hal ini bersinggungan dengan studi dokumenter. Penulis melakukan pengamatan langsung di Perpustakaan Politeknik Keuangan Negara STAN pada tanggal 10 Februari 2020 sampai dengan 3 April 2020.

\section{HASIL PENELITIAN}

\subsection{Praktik penyiangan buku ditinjau dari perspektif Pemusnahan BMN}

Berdasarkan wawancara yang penulis lakukan, Unit Perpustakaan Politeknik Keuangan Negara STAN belum pernah melaksanakan pemusnahan buku atau monografi sebagai tindak lanjut dari proses penyiangan yang telah dilakukan. Berdasarkan PMK Nomor 83 Tahun 2016 tentang Tata Cara Pelaksanaan Pemusnahan dan Penghapusan Barang Milik Negara, pemusnahan merupakan tindakan memusnahkan fisik dan/atau kegunaan BMN. Dalam hal ini, Politeknik Keuangan Negara STAN khususnya Unit Perpustakaan tidak pernah melakukan pemusnahan karena setiap barang masih memiliki nilai yang dapat dioptimalisasikan yaitu dengan cara dilelang.

Buku-buku yang ada di Unit Perpustakaan Politeknik Keuangan Negara STAN tidak pernah sama sekali dimusnahkan. Sesuai ketentuan dalam Peraturan Pemerintah Nomor 28 Tahun 2020, Menteri Keuangan mempunyai dua fungsi yaitu: a. Pengelola Barang (cq. DJKN).

b. Pengguna Barang (cq. Sekretariat Jenderal Kementerian Keuangan).

Dalam pengelolaan Barang Milik Negara (BMN), tentunya Kementerian Keuangan harus memberikan contoh nyata, sehingga dapat menjadi acuan bagi kementerian dan lembaga lainnya. Salah satu langkahnya yaitu mewujudkan 4T (Tertib Fisik, Tertib Hukum, Tertib Administrasi, dan Tingkatkan PNBP) yang merupakan pembaharuan dari 3T (Tertib Fisik, Tertib Hukum, Tertib Administrasi) (DJKN, 2016). Dengan tidak melakukan pemusnahan buku maka Politeknik Keuangan Negara STAN telah mengaplikasikan 4T dan dengan adanya kegiatan lelang buku, maka Politeknik Keuangan Negara STAN telah meningkatkan PNBP dari pelelangan barang.

\subsection{Praktik penyiangan buku ditinjau dari perspektif Penghapusan BMN}

Lain halnya dengan pemusnahan yang sama sekali tidak dilakukan, penyiangan buku yang dilanjutkan dengan proses penghapusan BMN sering dilakukan oleh Politeknik Keuangan Negara STAN walaupun tidak setiap tahun selalu dilakukan. Berdasarkan PMK Nomor 83 Tahun 2016 tentang Tata Cara Pelaksanaan Pemusnahan dan Penghapusan Barang Milik Negara, penghapusan yaitu tindakan menghapus BMN dari daftar barang dengan menerbitkan keputusan dari pejabat yang berwenang untuk membebaskan Pengelola Barang, Pengguna Barang, dan/ atau Kuasa Pengguna Barang dari tanggung jawab administrasi dan fisik atas barang yang berada dalam penguasaannya. Subbagian Pengelolaan Aset dan Kerumahtanggan melakukan aktivitas penghapusan monografi di Unit Perpustakaan Politeknik Keuangan Negara STAN dengan tata cara yang tertera pada:

a. PMK Nomor 83 Tahun 2016 tentang Tata Cara Pelaksanaan Pemusnahan dan Penghapusan Barang Milik Negara

b. Surat Edaran Menteri Keuangan Nomor 36 Tahun 2014 tentang Pedoman Penghapusan Barang Milik Negara di Lingkungan Kementerian Keuangan.

Selain itu, pelaksanaan penghapusan ini juga berpedoman pada KMK 520/KMK.01/2015 tentang Pendelegasian Sebagian Wewenang Menteri Keuangan Selaku Pengguna Barang kepada Pejabat Struktural dan Kuasa Pengguna Barang kepada Pejabat Struktural dan Kuasa Pengguna Barang di Lingkungan Kementerian Keuangan yang telah diubah dengan KMK 32/KMK.01/2020 tentang Pelimpahan Kewenangan Menteri Keuangan Selaku Pengguna Barang dalam Bentuk Mandat kepada Para Pejabat di Lingkungan Kementerian Keuangan.

Penghapusan koleksi buku di Politeknik Keuangan Negara STAN termasuk dalam penghapusan yang disebabkan karena pemindahtanganan yaitu lelang. Pelelangan buku yang ada pada Unit Perpustakaan Politeknik Keuangan Negara STAN dilakukan oleh pihak di luar PKN STAN, dalam hal ini, Direktorat Jenderal 
Kekayaan Negara atas usulan dari Politeknik Keuangan Negara STAN. Tata cara pemindahtanganan ini dilakukan berdasarkan Peraturan Menteri Keuangan Nomor 111 Tahun 2016 tentang Tata Cara Pelaksanaan Pemindahtanganan Barang Milik Negara.

Pada tanggal 25 Oktober 2017, Kepala Biro Perlengkapan Sekretariat Jenderal Kementerian Keuangan menyetujui penghapusan Barang Milik Negara sebanyak 26.918 ekslempar Monografi dengan nilai perolehan sebesar Rp1.850.965 dengan nilai limit terendah penjualannya sebesar Rp50.089.500. Berdasarkan Risalah Lelang, pada tanggal 18 Desember 2017 Barang Milik Negara tersebut telah terjual dengan harga sebesar Rp50.100.000. Kemudian tanggal 19 Desember 2017, berdasarkan Berita Acara Serah Terima telah dilakukan serah terima monografi tersebut kepada pemenang lelang.

Pada tanggal 28 Agustus 2018, Kepala Kantor Pelayanan Kekayaan Negara dan Lelang Tangerang II atas nama Menteri Keuangan, menyetujui penjualan buku sebanyak 15.971 ekslempar yang memiliki total nilai perolehan sebesar Rp815.641.123 dengan nilai limit terendah penjualan sebesar Rp20.104.800. Pada tanggal 17 Desember 2018 berdasarkan Salinan Risalah Lelang, dinyatakan bahwa buku tersebut telah terjual dengan harga total sebesar Rp32.777.777. Selanjutnya pada tanggal 21 Desember 2018 dilakukan serah terima Barang Milik Negara tersebut kepada pemenang lelang. Penghapusan monografi pada Unit Perpustakaan Politeknik Keuangan Negara STAN pada tahun 2018 dan 2019, secara singkat dapat dilihat pada tabel 1.

Berdasarkan Keputusan Sekretaris BPPK Nomor 18 Tahun 2018 tentang Penghapusan Barang Milik Negara pada Politeknik Keuangan Negara STAN, ada 3 penyebab penghapusan monografi pada Unit Perpustakaan Politeknik Keuangan Negara STAN, antara lain:

a. Barang dalam kondisi rusak berat;

b. Usang, dan

c. Tidak relevan karena tidak sesuai dengan perkembangan jaman atau modernisasi.

Sedangkan berdasarkan Keputusan Sekretaris BPPK Nomor 20 Tahun 2019 tentang Penghapusan Barang Milik Negara pada Politeknik Keuangan Negara STAN hanya terdapat satu alasan penghapusan buku yaitu buku yang akan dihapuskan sudah tidak terpakai lagi. Buku-buku yang akan dihapuskan tentu sudah tidak relevan lagi dengan perkembangan jaman atau bahkan kurikulum yang digunakan oleh Politeknik Keuangan Negara STAN dikarenakan buku-buku tersebut sudah terlalu tua yang diperoleh sepuluh atau lima belas dan bahkan dua puluh tahun yang lalu seperti yang tercantum dalam Tabel 2.

Dari 42.889 ekslempar buku, hanya 3 ekslempar saja yang diperoleh pada tahun 2015, sisanya diperoleh pada tahun 2000 hingga 2012. Ketiga buku tersebut antara lain: a. Corporate Governance sebanyak 1 ekslempar;

b. Cost Accounting: a managerial accounting 14E sebanyak 1 ekslempar; dan

c. Accounting 8ed sebanyak 1 ekslempar.

Proses Penghapusan atas buku yang ada di Unit Perpustakaan dikoordinasikan oleh Subbagian Aset dan Kerumahtanggaan yang didukung oleh Unit Perpustakaan. Berikut ini penyebab dilakukannya penghapusan koleksi di Unit Perpustakaan PKN STAN, antara lain:

a. Sudah keluar edisi terbaru dari buku tersebut.

IImu pengetahuan selalu mengalami perubahan dan perbaikan sehingga buku pasti mengalami perubahan juga contohnya seperti pembaharuan edisi. Selain itu, buku yang sudah terlampau tua biasanya sudah tidak relevan dengan materi yang dipelajari dewasa ini.

b. Penggunaannya tidak optimal.

Walaupun Unit Perpustakaan Politeknik Keuangan Negara STAN sudah meminta usulan pengadaan monografi dari pihak-pihak terkait seperti jurusan maupun pemustaka saat pelaksanaan pengadaan monografi, ada beberapa buku yang ternyata penggunaannya terbatas. Hal tersebut tentu membuat penggunaan buku menjadi tidak optimal. Selain itu, buku-buku yang sudah rusak dan sudah out of date membuat penggunaan menjadi tidak optimal.

c. Kerusakan pada buku.

Walaupun Unit Perpustakaan Politeknik Keuangan Negara STAN sudah melakukan pemeliharaan buku, kerusakan pada buku tidak dapat dielakkan. Menurut Martoatmodjo (1933) ada 3 faktor utama penyebab kerusakan pada buku, antara lain:

1) Faktor Manusia, seperti penggunaan buku.

2) Faktor Biota, seperti serangga, mikroorganisme, dan jamur.

3) Faktor Fisika, seperti debu, cahaya, suhu dan kelembaban udara.

d. Keterbatasan tempat penyimpanan.

Seiring berjalannya waktu pasti akan ada updating koleksi dan pengadaan buku baru dari situlah muncul keterbatasan tempat. Selain itu, penggunaan buku yang tidak optimal juga membuat tempat penyimpanan buku menjadi terbatas seperti pada Ruang Literatur di Perpustakaan Politeknik Keuangan Negara STAN.

Berdasarkan keempat alasan tersebut, maka Unit Perpustakaan Politeknik Keuangan Negara STAN membuat usulan penghapusan koleksi yang berupa Nota Dinas. Proses pembuatan usulan penghapusan monografi, antara lain:

a. Menempatkan buku ke ruang penghapusan.

Buku yang akan dihapuskan akan dikeluarkan dari Ruang Literasi, Ruang Sirkulasi, dan Ruang Referensi. Kemudian akan dipindahkan ke Ruang Penghapusan yang terletak di sayap kanan dan sayap kiri Perpustakaan Politeknik Keuangan Negara STAN. Perlu digarisbawahi tidak semua 
buku yang sudah usang akan dihapuskan, Unit Perpustakaan tetap akan menyisihkan $3-5$ ekslempar untuk dijadikan arsip. Sehingga buku yang akan dijadikan arsip tersebut tidak ikut dipindahkan ke Ruang Penghapusan.

b. Mendata buku yang akan dihapus.

Setelah semua buku yang akan dihapuskan dipindahkan ke Ruang Penghapusan, kegiatan selanjutnya yaitu melakukan pendataan buku yang akan dihapuskan. Data yang dituliskan pada usulan penghapusan monografi yaitu judul buku, pengarang, penerjemah, penerbit, edisi, tahun, jumlah, alasan penghapusan, dan foto.

c. Membuat Nota Dinas Usulan Penghapusan Monografi.

Nota Dinas dibuat oleh bagian administrasi Unit Perpustakaan Politeknik Keuangan Negara STAN berdasarkan data Usulan Penghapusan Monografi sehingga isi Nota Dinas sama dengan data Usulan Penghapusan Monografi, hanya saja ditambah tiga data lagi yaitu jumlah awal, jumlah penambahan, dan keterangan. Penambahan tiga data tersebut dikarenakan ada tambahan buku lagi saat sudah dilakukan pendataan. Nota dinas ini kemudian diteruskan ke bagian Subbagian Aset dan Kerumahtanggaan.

Setelah Nota Dinas Usulan Penghapusan Monografi diterima oleh Subbagian Aset dan Kerumahtanggaan, dimulailah proses penghapusan monografi yang sepenuhnya dilakukan oleh Subbagian Aset dan Kerumahtanggaan. Tata cara penghapusan monografi yang tertulis secara gamblang pada Surat Edaran Nomor 36 Tahun 2014 tentang Pedoman Penghapusan Barang Milik Negara di Lingkungan Kementerian Keuangan yaitu:

a. Direktur Politeknik Keuangan Negara STAN selaku Kuasa Pengguna Barang membentuk Tim Internal penghapusan Barang Milik Negara. Jika diperlukan, Tim Internal dapat melibatkan Penilai atau instansi teknis yang berkompeten untuk melakukan penilaian Barang Milik Negara. Tim Internal penghapusan Barang Milik Negara melakukan penelitian Barang Milik Negara yang akan dihapuskan, meliputi: penelitian data administratif, kondisi fisik, dan aspek yuridis, dan membantu dalam pelaksanaan proses pelelangan. Hasil penelitian tersebut dituangkan dalam Berita Acara Penelitian dan Pemeriksaan. Berita Acara dimaksud selanjutnya dilaporkan kepada Kuasa Pengguna Barang.

b. Berdasarkan Berita Acara Penelitian dan Pemeriksaan tersebut, Kuasa Pengguna Barang mengusulkan kepada Pengguna Barang melalui Pembantu Pengguna Barang Eselon I disertai dengan:

1) Penjelasan dan pertimbangan penjualan;

2) Data administratif, antara lain mengenai tahun perolehan, spesifikasi/identitas teknis, keputusan penetapan status penggunaan, bukti kepemilikan, nilai perolehan, nilai buku, dan nilai limit terendah penjualan;
3) Kondisi fisik Barang Milik Negara;

4) Kajian yuridis; dan

5) Dua rangkap dokumen pendukung meliputi:

a) Daftar Lampiran Barang Milik Negara yang diusulkan untuk dihapus (disampaikan dalam bentuk hardcopy dan softcopy);

b) Keputusan pembentukan Tim Internal penghapusan;

c) Berita Acara Penelitian dan Pemeriksaan Barang Milik Negara;

d) Surat Keterangan Penghentian Penggunaan Barang Milik Negara dari Kuasa Pengguna Barang;

e) Foto terkini berwarna Barang Milik Negara yang akan dihapuskan;

f) Fotokopi dokumen kepemilikan;

g) Laporan Kondisi Barang Rusak Berat;

h) Surat Pernyataan Tanggung Jawab Nilai Limit bermeterai dari Kuasa Pengguna Barang;

i) Surat Pernyataan tidak mengganggu tugas pokok dan fungsi bermeterai dari Kuasa Pengguna Barang;

j) Surat Pernyataan tidak sebagai dasar pengajuan anggaran bermeterai dari Kuasa Pengguna Barang;

k) Keterangan Penelitian/Pemeriksaan Teknis dari Dinas terkait (Dinas Perhubungan untuk kendaraan bermotor, Dinas Pekerjaan Umum untuk tanah dan/atau bangunan);

I) Laporan Barang Kuasa Pengguna Intrakomptabel dan Ekstrakomptabel;

m) Fotokopi salinan keputusan penetapan status penggunaan.

c. Pengguna Barang melakukan kajian lebih lanjut atas usulan yang disampaikan oleh Pembantu Pengguna Barang Eselon I. Jika usulan tersebut disetujui, Pengguna Barang menyampaikan usul penjualan Barang Milik Negara kepada Pengelola Barang yang disertai dengan:

1) Penjelasan dan pertimbangan penjualan;

2) Data administratif seperti yang dijelaskan pada poin b angka 2; dan

3) Dokumen pendukung seperti yang dijelaskan pada poin b angka 5 .

d. Berdasarkan persetujuan pemindahtanganan berupa penjualan Barang Milik Negara dari Pengelola Barang, Pengguna Barang memerintahkan Kuasa Pengguna Barang melaksanakan penjualan BMN secara lelang melalui Kantor Pelayanan Kekayaan Negara dan Lelang setempat dan dituangkan dalam Berita Acara Serah Terima BMN.

e. Jika proses lelangnya belum selesai setelah dua bulan perintah dari Pengguna Barang diterbitkan, Kuasa Pengguna Barang wajib melaporkan perkembangan proses penjualan secara lelang kepada Pengguna Barang.

f. Jika proses penjualan secara lelang terlaksana dengan lancar, Kuasa Pengguna Barang 
menyampaikan laporan pelaksanaan pemindahtanganan Barang Milik Negara tersebut kepada Pengguna Barang paling lambat satu minggu sejak Berita Acara Serah Terima BMN, dengan melampirkan Berita Acara Serah Terima BMN dan bukti setor ke rekening Kas Umum Negara.

g. Berdasarkan Berita Acara Serah Terima BMN, Pengguna Barang menerbitkan keputusan penghapusan Barang Milik Negara untuk menghapus Barang Milik Negara dari Daftar Barang Pengguna dan/atau Daftar Barang Kuasa Pengguna paling lama dua bulan sejak tanggal Berita Acara Serah Terima BMN.

h. Kuasa Pengguna Barang menyampaikan laporan penghapusan BMN kepada Pengelola Barang dengan ditembuskan kepada Pengguna Barang paling lama satu bulan sejak keputusan Penghapusan BMN ditandatangani dengan melampirkan keputusan Penghapusan BMN disertai dengan hal-hal sebagai berikut:

1) risalah lelang dan/atau Berita Acara Serah Terima, dalam hal pemindahtanganan dilakukan dalam bentuk penjualan secara lelang;

2) perjanjian penjualan dan/atau Berita Acara Serah Terima, dalam hal pemindahtanganan dilakukan dalam bentuk penjualan tanpa lelang; dan

3) Berita Acara Serah Terima, dalam hal pemindahtanganan dilakukan dalam bentuk tukar menukar atau Penyertaan Modal Pemerintah Pusat.

i. Berdasarkan laporan Penghapusan Barang Milik Negara tersebut, Pengelola Barang melakukan penghapusan BMN dari Daftar Barang Milik Negara.

j. Perubahan Daftar Barang Pengguna dan/atau Daftar Barang Kuasa Pengguna sebagai akibat dari penghapusan, dicantumkan dalam Laporan Semesteran dan Laporan Tahunan Pengguna Barang dan/atau Kuasa Pengguna Barang Kementerian Keuangan.

k. Perubahan Daftar Barang Milik Negara sebagai akibat dari Penghapusan BMN karena Pemindahtanganan harus dicantumkan dalam Laporan Barang Milik Negara Semesteran dan Tahunan.

Dalam pelaksanaan Penghapusan Barang Milik Negara berupa Buku pada Unit Perpustakaan Politeknik Keuangan Negara STAN, Subbagian Aset dan Kerumahtanggaan menggunakan dua aplikasi pendukung yaitu SAKTI (Sistem Aplikasi Keuangan Tingkat Instansi) dan SIMAN (Sistem Informasi Manajemen Aset Negara). Aplikasi SAKTI diperlukan saat perubahan kondisi, penghentian, penggunaan, usulan penghapusan, dan penghapusan. Sedangkan Aplikasi SIMAN dari DJKN digunakan saat terjadi penjualan dan pemindahtanganan. Adapun tata cara penginputan tiap proses pada tiap aplikasi adalah sebagai berikut: a. Perubahan Kondisi dengan Aplikasi SAKTI

1) Memilih menu RUH kemudian pilih Transaksi BMN kemudian pilih Perubahan dan yang terakhir pilih Perubahan Kondisi.

2) Kemudian tekan tombol untuk merekam data.

3) Setelah data diisi lengkap, tekan tombol simpan untuk menyimpan data tersebut.

4) Apabila data dan perekaman telah diyakini benar langkah selanjutnya yaitu melakukan validasi pada user validator lalu persetujuan pada user approver.

b. Penghentian Penggunaan dengan Aplikasi SAKTI

1) Memilih menu RUH kemudian pilih Transaksi BMN kemudian Penghentian Penggunaan selanjutnya Penghentian Penggunaan.

2) Kemudian tekan tombol untuk merekam data. List Kode Barang yang tampil apabila memilih status BMN RB/U/H adalah daftar barang yang telah direkam rusak berat sebelumnya, apabila memilih status Non RB/U/H maka list kode barang akan tampil semua.

3) Setelah data diisi lengkap, tekan tombol simpan untuk menyimpan data tersebut.

4) Apabila data dan perekaman telah diyakini benar langkah selanjutnya yaitu melakukan validasi pada user validator lalu persetujuan pada user approver.

c. Usulan Penghapusan dengan Aplikasi SAKTI

1) Memilih menu RUH kemudian pilih Transaksi BMN kemudian pilih Usulan Penghapusan BMN selanjutnya pilih Pencatatan Barang Yang Akan Dihapuskan.

2) Kemudian tekan tombol untuk merekam data. List Kode Barang yang tampil apabila memilih status Henti Guna adalah daftar barang yang telah direkam Penghentian Penggunaan sebelumnya, sementara status Non Henti Guna maka list kode barang akan tampil semua.

3) Setelah data diisi lengkap, tekan tombol simpan untuk menyimpan data tersebut.

4) Apabila data dan perekaman telah diyakini benar langkah selanjutnya yaitu melakukan validasi pada user validator lalu persetujuan pada user approver.

d. Penghapusan dengan Aplikasi SAKTI

1) Memilih menu RUH kemudian pilih Transaksi BMN selanjutnya pilih Penghapusan dan yang terakhir pilih Penghapusan lagi.

2) Kemudian tekan tombol untuk merekam data. List Kode Barang yang tampil adalah barang yang telah dilakukan penginputan Usulan Penghapusan BMN sebelumnya.

3) Setelah data diisi lengkap, tekan tombol simpan untuk menyimpan data tersebut.

4) Apabila data dan perekaman telah diyakini benar langkah selanjutnya yaitu melakukan validasi pada user validator lalu persetujuan pada user approver.

e. Penjualan dengan Aplikasi SIMAN 
1) Pilih menu perekaman PNBP kemudian pilih penjualan BMN

2) Pilih PNBP baru yang selanjutnya akan muncul Surat Persetujuan. Pilih Surat Persetujuan dan tekan simpan.

3) Selanjutnya isi data yang diminta berdasarkan sumber data dan unggah sumber data dengan format pdf.

4) Kemudian lakukan penginputan aset yang dijual dengan cara pilih tombol tambah kemudian centang dokumen, lalu tekan tombol pilih dan simpan.

5) Terakhir lakukan penginputan PNBP kemudian pilih tombol simpan.

f. Pemindahtanganan dengan Aplikasi SIMAN

1) Pilih fitur Perekaman SK, kemudian pilih menu Tindaklanjut kemudian pilih PSP maka akan muncul tampilan surat keputusan yang telah di rekam pada menu Perekaman SK.

2) Pilih salah satu SK, maka akan muncul formulir perekaman SK.

3) Tekan dua kali pada BMN/aset atau tekan disebelah kanan pada tombol Tindak Lanjut untuk merekam data.

4) Pilih tindak lanjut berupa pemindahtanganan, kemudian klik tombol Simpan.d

4.3. Permasalahan Penghapusan Buku pada Unit Perpustakaan Politeknik Keuangan Negara STAN

Politeknik Keuangan Negara STAN sangat erat kaitannya dengan Kementerian Keuangan sehingga nilai-nilai Kementerian Keuangan yang meliputi Integritas, Profesionalisme, Sinergi, Pelayanan, dan Kesempurnaan harus diterapkan dalam setiap aktivitas. Walaupun sudah menerapkan nilai-nilai Kementerian Keuangan, tetap ditemui beberapa permasalahan saat pelaksanaan Penghapusan Monografi di Unit Perpustakaan Politeknik Keuangan Negara STAN, antara lain:

a. Sulit menyimpan fisik buku yang akan dihapus agar tidak mengalami perubahan kondisi dan volume karena tidak ada pool yang aman dan terlindung dari risiko suhu ekstrim atau rayap atau hilang. Selain itu, tidak ada kepastian kapan buku yang akan dihapus dapat dipindahtangankan dikarenakan harus menunggu putusan lelang dari Direktorat Jenderal Kekayaan Negara. Di sisi lain, adanya penambahan bukubuku yang akan dihapuskan di periode selanjutnya. Oleh karena itu, munculah keterbatasan tempat penyimpanan fisik buku yang akan dihapuskan.

b. Akurasi data fisik perpustakaan baik dalam jumlah maupun judul dibanding data sistem aset kurang baik.

c. Kurangnya tenaga saat memindahkan buku yang akan dihapus dari Ruang Literasi, Ruang Sirkulasi, dan Ruang Referensi ke Ruang Penghapusan dikarenakan tidak sedikitnya jumlah buku yang dihapuskan. d. Sangat memakan waktu dalam pengolahan data di aplikasi. Ada 4 tahap yang harus diinput pada aplikasi SAKTI (perubahan kondisi, penghentian penggunaan, usulan penghapusan, dan penghapusan) dan 2 tahap pada aplikasi SIMAN (pemindahtanganan dan penjualan). Semuanya manual dan diinput satu-persatu sesuai jumlah monografi yang akan dihapus (kurang lebih 4.00030.000 sekali penghapusan).

e. Penentuan nilai limit penjualan berdasarkan perkiraan tonase kubik dikali harga kertas bekas perkilo.

\section{KESIMPULAN DAN SARAN}

Berdasarkan hasil penelitian penulis, dapat diambil kesimpulan sebagai berikut:

a. Penyiangan buku pada perpustakaan Politeknik Keuangan Negara STAN tidak ada yang diproses sampai dengan kegiatan pemusnahan BMN. Hal ini mencerminkan bahwa Politeknik Keuangan Negara STAN berupaya untuk mengoptimalisasi BMN yang ada. Buku-buku yang sudah rusak, usang, dan tidak relevan dengan materi akan dihapuskan dengan pemindahtanganan. Penghapusan dengan pemindahtanganan ini memiliki dua keuntungan yaitu dapat menambah ruang untuk buku baru serta dapat menambah Penerimaan Negara Bukan Pajak.

b. Penyiangan buku pada Perpustakaan Politeknik Keuangan Negara STAN secara rata-rata dilanjutkan sampai dengan proses Penghapusan BMN. Prose tersebut telah sesuai dengan aturan yang berlaku.

c. Namun, walaupun penghapusan sudah dilaksanakan sesuai dengan aturan yang berlaku, masih terdapat beberapa permasalahan dalam prosesnya. Permasalahan tersebut antara lain: Sumber daya manusia, keterbatasan tempat, akurasi data fisik, serta penentuan nilai limit penjualan.

Adapun saran untuk penelitian ini ke depannya antara lain:

a. Pada penelitian kali ini, lokus penelitian penulis yaitu Unit Perpustakaan Politeknik Keuangan Negara STAN sehingga penulis tidak dapat melihat aspek pemusnahan barang milik negara berupa buku secara lebih luas. Oleh karena itu akan lebih baik jika penelitian yang diselenggarakan ke depan dapat membahas mengenai pemusnahan barang milik negara berupa buku pada satuan kerja lain.

b. Penulis lain dapat melanjutkan penelitian ini dengan berfokus ke buku elektronik di Unit Perpustakaan Politeknik Keuangan Negara STAN atau buku cetak dan elektronik di satuan kerja lain dikarenakan fokus penulis saat ini yaitu hanya berfokus pada monografi yang berbentuk cetak pada Unit Perpustakaan Politeknik Keuangan STAN.

\section{IMPLIKASI DAN KETERBATASAN}

Dalam penelitian ini penulis membatasi pembahasan terkait penyiangan buku yang ditinjau dari perspektif penghapusan dan pemusnahan BMN 
yang terjadi di Perpustakaan Politeknik Keuangan Negara STAN. Adapun pengambilan data dan penulisan berlangsung pada tanggal 10 Februari 2020 sampai 7 Juli 2020.

\section{DAFTAR PUSTAKA (REFERENCES)}

\section{Buku dan Sumber Lain}

Almah, H. (2012). Pemilihan dan Pengembangan Koleksi Perpustakaan. Makassar: Universitas Alauddin.

Arimbawa, I Ketut dkk. 2013. Penyelesaian BMN Rusak Berat/Hilang pada Kementerian Keuangan. Jakarta: Media Kekayaan Negara. HIm 6-10

Basri, Elly Julia. 2019. Kasus Digitalisasi PDII-LIPI >< Kebangkitan Pustakawan Indonesia. Diakses tanggal 10 Februari 2020, dari isipii.org/artikel

Dea, Anya Q. 2014. Faktor Penyebab Kerusakan Koleksi Buku di 3 Unit Perpustakaan Politeknik Kesehatan Jakarta II. Depok: Universitas Indonesia.

Direktorat Jenderal Kekayaan Negara. 2015. Sistem Informasi Manajemen Aset Negara Tingkat $U A K P B$. Jakarta: Direktorat Jenderal Kekayaan Negara

DJKN. (2016). Pengelolaan BMN Sudah Diupgrade dari 3T jadi 4T. Retrieved November 20, 2020, from https://www.djkn.kemenkeu.go.id/berita/baca/ 10467/Pengelolaan-BMN-Sudah-Diupgradedari-3T-jadi-4T.html

Direktorat Jenderal Perbendaharaan. 2014. Buku Pintar SAKTI. Lampung: Kanwil Direktorat Jenderal Perbendaharaan.

djkn.kemenkeu.go.id. (2016, 31 Mei). Pengelolaan BMN Sudah Diupgrade dari 3T jadi 4T. Diakses tanggal 20 Juni 2020, dari https://www.djkn.kemenkeu.go.id/berita/baca/ 10467/Pengelolaan-BMN-Sudah-Diupgradedari-3T-jadi-4T

Iskandar. 2009. Metodologi Penelitian Kualitatif. Jakarta: Gaung Persada (GP Press).

Johnson, P. (2009). Fundamentals of Collection Development and Management. Chicago: American Library Association.

Khusniatulula, Aning dkk. 2020. Laporan Praktik Kerja Lapangan pada Unit Perpustakaan Politeknik Keuangan Negara STAN. Tangerang Selatan: Politeknik Keuangan Negara STAN.

Manar, A. (2010). Pengembangan Koleksi UPT Perpustakaan IAIN AR-Ranry. Jurnal Libraria, 2(3), 19-23.

Martoatmodjo, Karmidi. 1993. Pemeliharaan Bahan Pustaka. Jakarta: Universitas terbuka.

Masridah, M. (2009). Kebijakan Penyiangan Koleksi di Badan Perpustakaan Daerah Provinsi Daerah Istimewah Yogyakarta. Universitas Islam Negeri Sunan Kalijaga.

Rahayu, A., \& Rahmah, E. (2013). Kegiatan Penyiangan Bahan Pustaka (Weeding) di Perpustakaan Universitas Negeri Padang. Ilmu Informasi Perpustakaan Dan Kearsipan, 2(1), 12-19. Retrieved from http://ejournal.unp.ac.id/index.php/iipk/article/v iew/2285

Ridwan, \& Rohana. (2020). Implementasi kebijakan penyiangan koleksi di upt perpustakaan universitas muhammadiyah mataram, 2(1), 1-16.

Sujana, J. G. (2011). Weeding : Membuat Akses Pada Koleksi Lebih Baik. Jurnal Pustakawan Indonesia, 11(1), 15-20.

Sujana, Y. Y. (2009). Pengembangan Koleksi. Jakarta: Universitas Terbuka.

Yusuf, Muri. 2014. Metode Penelitian: Kuantitatif, Kualitatif, dan Penelitian Gabungan. Jakarta: Kencana.

Zed, Mestika. 2014. Metode Penelitian Kepustakaan. Jakarta: Yayasan Pustaka Obor Indonesia.

Dokumen Publik atau Peraturan Perundangundangan

Undang-Undang Republik Indonesia Nomor 1 Tahun 2004, tentang Perbendaharaan Negara.

Undang-Undang Nomor 43 Tahun 2007 tentang Perspustakaan.

Undang-Undang Republik Indonesia Nomor 3 Tahun 2017, tentang Sistem Perbukuan.

Undang-Undang Nomor Nomor 43 Tahun 2007, tentang Perpustakaan.

Peraturan Pemerintah Republik Indonesia Nomor 28 Tahun 2020, tentang Perubahan atas Peraturan Pemerintah Nomor 27 Tahun 2014 tentang Pengelolaan Barang Milik Negara/Daerah

Peraturan Kepala Perpustakaan Nasional Republik Indonesia (2017). Retrieved from https://jdih.perpusnas.go.id/file_peraturan/Perk a_13_2017_SNP_Perpustakaan_Perguruan_Tingg i.pdf

Peraturan Menteri Keuangan nomor 137/PMK.01/2015 tentang organisasi dan tata kerja Politeknik Keuangan Negara STAN.

Peraturan Menteri Keuangan Republik Indonesia Nomor 83/PMK.06/2016, tentang Tata Cara Pelaksanaan Pemusnahan dan Penghapusan Barang Milik Negara.

Peraturan Menteri Keuangan Republik Indonesia Nomor 111/PMK.06/2016, tentang Tata Cara Pelaksanaan Pemindahtanganan Barang Milik Negara.

Peraturan Menteri Keuangan Republik Indonesia Nomor 159/PMK.05/2018, tentang Pelaksanaan Piloting Sistem Aplikasi Keuangan Tingkat Instansi.

Keputusan Menteri Keuangan Nomor 520 Tahun 2015 tentang Pendelegasian Sebagian Wewenang Menteri Keuangan Selaku Pengguna Barang kepada Pejabat Struktural dan Kuasa Pengguna Barang kepada Pejabat Struktural dan Kuasa Pengguna Barang di Lingkungan Kementerian.

Surat Edaran Menteri Keuangan Nomor 36 Tahun 2014, tentang Pedoman Penghapusan Barang Milik Negara di Lingkungan Kementerian Keuangan. 


\section{ILUSTRASI TABEL}

Tabel 1. Penghapusan Monografi Tahun 2018 \& 2019

\begin{tabular}{|c|c|c|c|c|}
\hline Tahun & Jumlah & Nilai Perolehan & Nilai Limit Terendah & Nilai Jual \\
\hline $\mathbf{2 0 1 8}$ & 26.918 & 1.850 .965 .190 & 50.089 .500 & 50.100 .000 \\
\hline $\mathbf{2 0 1 9}$ & 15.971 & 815.641 .123 & 20.104 .800 & 32.777 .777 \\
\hline Total & 42.889 & 2.666 .606 .313 & 70.194 .300 & 82.877 .777 \\
\hline
\end{tabular}

Sumber: PKN STAN, 2020, diolah Penulis

Tabel 2. Data Tahun Perolehan Buku yang akan Dihapuskan

\begin{tabular}{|c|c|c|}
\hline Tahun & Acuan & Rentang Tahun Perolehan \\
\hline $\mathbf{2 0 1 8}$ & Keputusan Sekretaris BPPK Nomor 18 Tahun 2018 & $2000-2015$ \\
\hline $\mathbf{2 0 1 9}$ & Keputusan Sekretaris BPPK Nomor 20 Tahun 2019 & $2000-2012$ \\
\hline
\end{tabular}

